\title{
EFFECT OF DIETARY OF VEGETABLE SOURCES AND FEED ADDITIVES ON SOME PRODUCTIVE, REPRODUCTIVE AND NUTRIENTS UTILIZATION OF MANDARAH HENS DURING THE LATE STAGE OF EGG PRODUCTION CYCLE.
}

\author{
M.M. Shehata and A. E. El - Abd
}

Animal Production Research Institute, Agriculture Research Center, Min. Agric.

\section{ABSTRACT}

A total number of 240 hens of Mandarah local strain aging 58 weeks of age was used in a factorial design (3 source of vegetable oil groups $x 4$ feed additives) up to 70 weeks of age. Hens were divided randomly into three treatment groups. The $1^{\text {st }}$ group was fed basal diet, $2^{\text {nd }}$ group was fed the basal diet containing $3 \%$ corn oil, $3^{\text {rd }}$ group was fed the basal diet containing $3 \%$ sunflower oil. Each treatment group was divided randomly into four subgroups. The $1^{\text {st }}$ subgroup was fed basal diet without any supplementation $t$, $2^{\text {nd }}$ group was supplemented with vitamin $C$ at $100 \mathrm{mg} / \mathrm{kg}$ diet, $3^{\text {rd }}$ subgroup was supplemented with kemzyme preparation at a rate of $0.05 \%$ of the diet, and the $4^{\text {th }}$ subgroup was supplemented with both of vitamin $C(100 \mathrm{mg} / \mathrm{kg}$ diet $)$ and kemzyme preparation at level $0.05 \%$ of the diet.

The results indicated that feeding laying hens on vegetable oil sources (corn or sunflower oil at 3\% diet) produced the best value of egg number, egg production, egg weight, egg mass, feed conversion and hell thickness as compared to those fed control diet.

However, chicks weight at hatching, values of serum cholesterol and yolk cholesterol were significantly $(P<0.05)$ effect due to corn oil treatment as compared to other treatment. The vegetable oil sources had a beneficial effect on the digestion coefficient values of DM, CP and EE\% and also improved the retained amount of calcium and phosphorus content as compared to the control diet.

On the other hand, hens fed diets supplemented with kemzyme only gave the best values of egg number, egg production and feed conversion. Hens fed diet supplemented with vitamin $C$ resulted in the best value of egg weight and egg mass, while the lowest value of feed intake was recorded by hens fed diet supplemented with the combination of vitamin $C$ and kemzyme preparation. The addition of vitamin $C$ and mixture of vitamin $C$ and kemzyme preparation gave the best values of egg shell quality, in almost coefficients of digestibility, calcium and phosphorus retention, fertility and hatchability and also the chick weight at hatching, while it was lower both of serum cholesterol and yolk cholesterol and also increase serum calcium and phosphorus content when compared to the other treatments. 
Interaction results indicated no significant for previous traits, except for feed intake, feed conversion and the values of serum cholesterol, yolk cholesterol and total lipid, which were significant $(P<0.05)$ affected.

Economic evaluation indicated that the use of oil (sunflower oil following corn oil) in supplementing layer diets improved NR and EE\% as compared to the non supplemented diet, while kemzyme preparation recorded the highest value of NR and EE\% follow by the mixture of vitamin $C$ with kemzyme preparation as compared to the other treatments.

Keywords: Vegetable oil sources, corn oil, sunflower oil, vitamin C, kemzyme preparation, performance of laying hens.

\section{INTRODUCTION}

The later stage of egg production cycle in a local chicken breeder is one of the kinds of stress (i.e., transport electric shocks, fasting, low or high ambient temperature) is known to have a negative effect on production and reproductive performance of layer chick, especially it is simultaneous with summer season usually, which can cause severe economic damage in the inferior egg shell quality and egg production characteristics of local layers. Egg characteristics and quality traits affected by late stage of egg production of the hen (Nagarajun et al., 1991; El-Wardany et al., 1994 and Szczerbinska, 1998).

Vegetable oils have been used to improve physical characteristics and to increase the caloric density of poultry rations. Dietary vegetable oil caused to improve efficiency of fed utilization by laying hens (Reid and Weber, 1975 ; Sell et al., 1979 and Matoes and Sell, 1980). Jensen et al. (1958) and Younis (1981) stated that egg weight and egg production in hens could be improved by the addition of corn oil to practical diets. Also, Amer (1977) showed that vegetable oils (soybean and sunflower oils) were significantly better in improving the average of egg weight than animal fats. Egg size is one aspect of production where considerable uncertainly has existed over linoleic acid requirements. This followed observations that addition of 3-5\% of maize oil to practical diets could markedly increase egg size in hens (Jensen et al., 1958 and Shutzye and Jensen, 1963). The responses have been greatest when essential-depleted hens have been studied (Menge et al., 1963) and have therefore been attributed to the linoleic acid content of the oils. As a result it widely held that laying hen had two requirements for linoleic acid $0.9 \%$ for physiological function and a deficient birds would have a high essential fatty acids requirement, initially at least in order to reverse the effect of the deficiency and build up reserves.

However, possess an innate ability to synthesize vitamin $\mathrm{C}$, so it is not a common practice to add ascorbic acid to poultry diets. Certain environmental, nutritional as well as pathological condition may increase ability (Perdue and Haxtun, 1986). It is a very powerful reducing agent that occurs naturally in living tissues and may function as an antioxidant for Vitamins A and E (Mohamed, 1998). 
Body energy stores was affected by supplemental vitamin $\mathrm{C}$ which used for energy purposes during periods of reduced energy intake (Mckee et al., 1997). Vitamin C, also had a beneficial effect during egg incubation and after health an embryonic development (Zakria and Al-Latif, 1998).

The use of enzymes in the birds diet has been successful in reducing the viscosity of digest and has led to an improvement in feed conversion efficiency (Bedford, 1997). El-Deek et al. (2003) reported that the addition of multi-enzyme mixture to $60 \%$ barley caused to improve egg number and egg mass in broiler hens. Moreover, addition of enzyme preparation to diets containing extruded full-fat soybeans produced an improvement of $2.2 \%$ reduction in the feed conversion ratio (Zanella et al., 1999).

The present study aimed to study the effect of using some vegetable oils sources (Corn oil and sunflower oil) and ascorbic acid, enzymes preparation as feed additives in layer diet on egg production characteristics, nutrients digestibility of Mandarah hens during the late stage of egg production cycle.

\section{MATERIALS AND METHODS}

The current experimental work was conducted at Sakha Research Station Kafr El-Sheikh, Animal Production Research Institute, Agriculture Research Center. The experimental period lasted for 20 weeks starting from June 2002.

A total number of 240 hens of Mandarah local strain, ageing 58 weeks of age was designed in a factorial trail (3 source of vegetable oil groups $\mathrm{x} 4$ feed additives) up to 70 weeks of age. Hens housed in individual cages and were divided randomly into three treatment groups. The $1^{\text {st }}$ group was fed basal diet, $2^{\text {nd }}$ group was fed the basal diet containing $3 \%$ corn oil, $3^{\text {rd }}$ group was fed the basal diet containing $3 \%$ sunflower oil. Each treatment group was divided randomly into four subgroups. The $1^{\text {st }}$ subgroup was fed basal diet without any supplementation diet, $2^{\text {nd }}$ was supplemented with vitamin C (100 mg / kg diet $), 3^{\text {rd }}$ subgroup was supplemented with kemzyme preparation $(0.05 \%)$ of the diet, and the $4^{\text {th }}$ subgroup was supplemented with both of vitamin C (100 mg / $\mathrm{kg}$ diet) and enzymes preparation $(0.05 \%)$ of the diet.

The ingredients and composition of the basal diet were used according to NRC (1994) as shown in Table 1. The chemical analysis of the basal diet was analyzed according to A.O.A.C. (1994). Two sources of oils diets (corn oil and sunflower oil) were replaced by $3 \%$ of the basal diet. Fatty acids composition of both of experimental oils and experimental diet are shown in Table 2. Vitamin C (commercially named vitamin C 20\%, where each $100 \mathrm{gm}$ contains 20 gm pure ascorbic acid) was used. The enzymes preparation (kemzyme) contained alphaanylase $(0.69 \%)$, beta-glucose $(0.65 \%)$, protease $(37.0 \%)$, lipase $(0.43 \%)$, cellulose $(0.42 \%)$ and bentonite $(1.7 \%)$. The vitamin C manufacture by the Memphis chemical Co. Cairo, A.R.E., while enzyme preparation manufacture by Kemin (European. N. V. Herentals) Belgium. 
Table (1): Composition and chemical analysis of the experimental diet.

\begin{tabular}{|c|c|c|c|}
\hline \multirow[t]{2}{*}{ Ingredients } & \multicolumn{3}{|c|}{ Experimental diets } \\
\hline & Control & Corn oil & Sunflower oil \\
\hline Yellow corn & 63.67 & 55.12 & 55.12 \\
\hline Soybean meal (44\%) & 24.57 & 24.12 & 24.12 \\
\hline Wheat bran & 2.00 & 8.0 & 8.00 \\
\hline Corn oil & 0.00 & 3.0 & 0.00 \\
\hline Sunflower oil & 0.00 & 0.0 & 3.0 \\
\hline Dicalcium-phosphate & 1.50 & 1.5 & 1.50 \\
\hline Limestone & 7.60 & 7.60 & 7.60 \\
\hline Vit.+Min. premix* & 0.30 & 0.30 & 0.30 \\
\hline \multirow[t]{2}{*}{ DL-Methionine } & 0.30 & 0.30 & 0.30 \\
\hline & 0.06 & 0.06 & 0.06 \\
\hline Total & 100 & 100 & 100 \\
\hline Crude protein ( $\mathrm{N} \times 6.25)$ & 15.76 & 15.73 & 15.74 \\
\hline \multicolumn{4}{|l|}{ Calculated values $^{* *}$ : } \\
\hline ME (kcal/kg) & 2710 & 2745 & 2746 \\
\hline $\mathrm{Ca}$ & 0.89 & 0.85 & 0.87 \\
\hline $\mathrm{P}$ & 0.59 & 0.51 & 0.50 \\
\hline $\mathrm{CF}$ & 3.47 & 3.75 & 3.78 \\
\hline Lysine & 0.81 & 0.83 & 0.82 \\
\hline Methionine & 0.32 & 0.31 & 0.30 \\
\hline \multicolumn{4}{|c|}{$\begin{array}{l}\text { * Vitamin and mineral premix was added } 3 \mathrm{~kg} / \text { ton of diet and supply } 1 \mathrm{~kg} \text { of diet with: A } 1000 \\
\text { IU, } \mathrm{D}_{3} 1000 \mathrm{IU}, \text { E10 mg, K } 31 \mathrm{mg}, \mathrm{B}_{2} 4 \mathrm{mg}, \mathrm{B}_{6} 1.5 \mathrm{mg} \text {, Pantothenic acid } 10 \mathrm{mg}, \mathrm{B}_{12} 0.01 \mathrm{mg} \text {, } \\
\text { Folic acid } 1 \mathrm{mg} \text {, Niacin } 20 \mathrm{mg} \text {, Biotin } 0.05 \mathrm{mg} \text {, Choline chloride } 500 \mathrm{mg}, \mathrm{Zn} 45 \mathrm{mg}, \mathrm{Cu} 3 \mathrm{mg} \text {, } \\
\text { Fe } 30 \mathrm{mg} \text {, I } 0.3 \mathrm{mg} \text {, Se } 0.1 \mathrm{mg}, \mathrm{Mn} 40 \mathrm{mg} \text { and Ethoxyquin } 3000 \mathrm{mg} \text {. } \\
\text { ** Calculated according to NRC (1994). }\end{array}$} \\
\hline
\end{tabular}

Artificial light was used beside the normal day light to provide 16-hour day photoperiod. Hens were offered feed and water ad libitum. Performance traits of laying hens were based on a 4 weeks interval through the experimental period, which lasted for 12 consecutive weeks from 58 to 70 weeks of age. Egg production traits including egg percentage, egg weight $(\mathrm{g})$, egg number and egg mass $(\mathrm{g} / \mathrm{d})$ were recorded and calculated daily. Feed intake (g/ hen /d) and feed conversion (feed/egg) were calculated for each 4 weeks. Egg quality measurements including egg yolk and shell weights $(\mathrm{g})$ and shell thickness $(\mathrm{mm})$ were recorded during the last period of study (58-70 weeks). Eggs produced from the beginning of the $58^{\text {th }}$ weeks up to the end of the experiment were incubated to determine the fertility and hatchability percentages and chick weight at hatch.

At the end of the experiment, 4 males of each group were individually kept in metabolic cages to determine the digestibility coefficient of nutrients in digestibility 
trails. Apparent absorption of calcium was calculated as the difference between calcium intake and calcium in excreta expressed as a percentage of calcium intake during the collection period. Calcium was determined by atomic absorption spectrophotometer. The proximate analysis of diets and excreta was done according to A.O.A.C. (1994).

Economical efficiency of egg production was calculated from the input-output analysis, which was calculated according to the price of the experimental diets and egg produced. The values of economical efficiency were calculated as the net revenue per unit of total cost. Data were analyzed by factorial analysis (3 x 4) using SAS (1994). Means having a significant Duncan's (Duncan, 1955). The statistical model of factorial trail was designed as the following:

$X_{i j k}=\mu+T_{i}+F_{j}+(T F)_{i j}+E_{i j k}$

Where:

$\mathrm{X}_{\mathrm{ijk}}=$ Any observation, $\mu=$ Overall mean, $\mathrm{T}_{\mathrm{i}}=$ Treatment groups $(1=1,5$ and 9)., $F_{j}=$ Interaction between treatment groups and feed additives $(i j=1, \ldots 12), E_{i j k}=$ Experimental error.

\section{RESULTS AND DISCUSSION}

Fatty acids composition of both of experimental oil and diets:

Results in Table (2) show that chemical analysis of fatty acids, corn oil contained the higher TSFAS (66.16\%) and the lower TUSFAS (33.84\%) while, sunflower oil contained the lower TSFAS (64.16\%) and the higher TUSFAS $(35.84 \%)$ as a percentage of the total and TUSFAS of experimental diets due to oil supplementation when compared to the control diet. Regarding the USFAS, corn oil had the higher percentage of PUSFAS (LA and LNA) followed sunflower oil. It contained $(93.62 \%)$ as the total whereas sunflower oil contained $(13.56 \%)$.

The increase in TUSFAS in the experimental diets was found to be mainly due to the increase in TPUSFAS (LA and LNA). Diets containing corn and sunflower oils gave the highest values as compared to control diet.

\section{Nutrients utilization:}

Results in Table (3) revealed that the vegetable oil sources had similar effects with insignificant differences in digestibility of nutrient values. However, corn oil, followed by sunflower oil diets had a beneficial effect on some the digestion coefficient values (DM, CP and EE\%) and also improved the retained amount of calcium and phosphorus as compared to the control diets. The results of the study reported herein are supported by El-Husseiny et al. (2002) who mentioned that corn oil improved the digestion coefficient values of almost all the nutrients and calcium and phosphorus retention. Hakansson (1975) found a lower digestibility of either extract with added high levels of fat or oil to chicken diets. The results obtained by 
Katongole and March (1980) showed that increasing the substitution level of lipids in laying hen diets improved calcium retention.

Table (2): Fatty acid composition of both of experimental oil and diets.

\begin{tabular}{|c|c|c|c|c|c|c|}
\hline \multirow{2}{*}{$\begin{array}{c}\text { Fatty acids } \\
\text { composition }(\%)\end{array}$} & \multirow{2}{*}{$\begin{array}{l}\text { No. of } \\
\text { carbo- } \\
\text { natoms }\end{array}$} & \multicolumn{3}{|c|}{ Experimental oils } & \multicolumn{2}{|c|}{ Experimental diet } \\
\hline & & $\begin{array}{c}\text { Corn } \\
\text { oil }\end{array}$ & $\begin{array}{c}\text { Sunflower } \\
\text { oil }\end{array}$ & Control & $\begin{array}{c}\text { Corn } \\
\text { oil }\end{array}$ & $\begin{array}{c}\text { Sunflower } \\
\text { oil }\end{array}$ \\
\hline LUA & $12: 0$ & 28.82 & 3.77 & 1.41 & 1.65 & 1.68 \\
\hline MA & 14:0 & 13.48 & 0.26 & 0.02 & 1.91 & 0.43 \\
\hline PA & 16:0 & 1.59 & 55.51 & 0.74 & 0.17 & 0.27 \\
\hline SA & 18:0 & 11.45 & 1.48 & 0.06 & 0.14 & 0.23 \\
\hline $\mathbf{A A}$ & $20: 0$ & 10.82 & 3.14 & 0.0 & 0.61 & 0.48 \\
\hline $\mathbf{O A}$ & $18: 1$ & 2.16 & 30.98 & 0.04 & 0.15 & 0.61 \\
\hline LA & $18: 2$ & 1.79 & 4.02 & 0.12 & 0.20 & 0.92 \\
\hline LNA & $18: 3$ & 29.89 & 0.84 & 0.0 & 0.24 & 0.07 \\
\hline TVFAs & - & 100 & 100 & 2.39 & 4.91 & 4.63 \\
\hline TSFAs & - & 66.16 & 64.16 & 2.23 & 4.40 & 3.03 \\
\hline TUSFAs & - & 33.84 & 35.84 & 0.16 & 0.51 & 1.60 \\
\hline MUSFAs/TUSFAs & - & 6.38 & 86.44 & 25.0 & 25.49 & 38.13 \\
\hline PUSFAs/TUSFAs & - & 93.62 & 13.56 & 75.0 & 74.51 & 61.87 \\
\hline TUSFAs : TSFAs & - & 0.51 & 0.56 & 0.07 & 0.12 & 0.53 \\
\hline
\end{tabular}

LUA: Lauric acid, MA: Myristic acid, PA; Polmitic acid, SA: Stearic acid, OA: Oleic acid, LA: Loinoleic acid, LNA: Linolenic acid, AA: Arachidic acid, TVFAs: Total saturated fatty acid, TUSFAs: Total unsaturated fatty acid, MUSFAs/TUSFAs: Relative monounsaturated fatty acids to total unsaturated fatty acids, PUSFAs/TUSFAs: Relative polyunsaturated fatty acid to total unsaturated fatty acids, TUSFAs : TSFAs: Ratio between total unsaturated fatty acids and total saturated fatty acids.

Addition laying hen diets with vitamin $\mathrm{C}$, kemzyme or a mixture of both improved values of digestion coefficients $(\mathrm{P}<0.05)$ for the almost all nutrients and also calcium and phosphorus retention when compared to the control diet. The same results were obtained by the findings of Soliman (2003) who reported that supplementing the diet with vitamin $\mathrm{C}$ enzyme mixture or both of them improved the digestion coefficient of DM, OM and also the retained calcium. In this regard Van der Klis et al. (1995) and Marsman et al. (1997) reported that enzyme treatment improved the dry matter digestibility and enhanced the apparent absorption of calcium. The first 
Table (4): Effect of dietary vegetable oils and some feed additives and their interaction between them on laying hen performance and feed utilization.

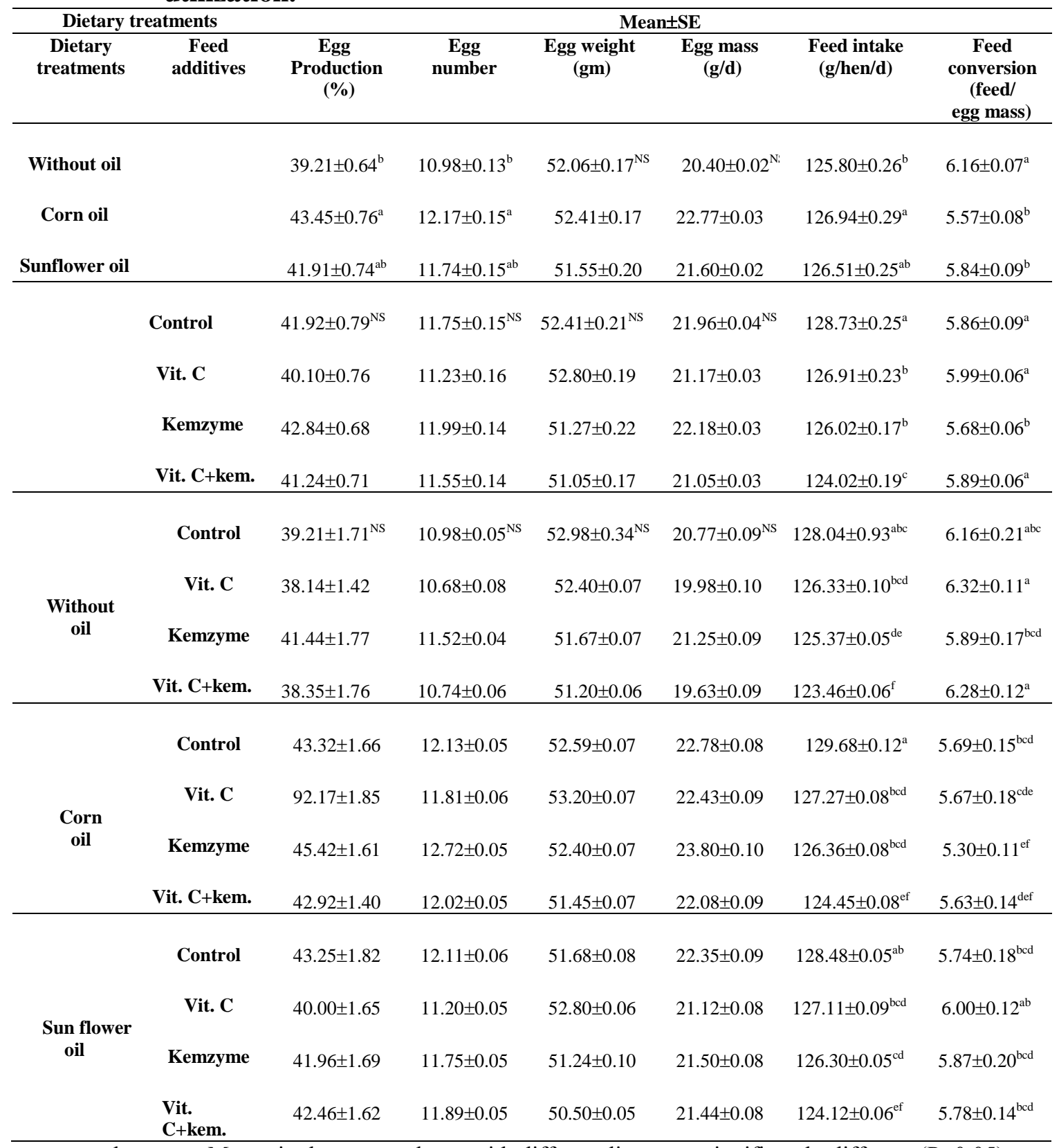

a, b, c.....e: Means in the same column with different litters are significantly different $(\mathrm{P}<0.05)$. 
related the improvement in nutrient utilization to decreasing the chime viscosity, while the second indicated that increasing chime viscosity did not affect apparent ideal nutrient digestibility.

The Interaction effects between dietary vegetable oils and treatments supplementation were not significant on all digestibility coefficients as shown in Table (3).

\section{Laying hen performance:}

Results in Table 4 showed that a significant $(\mathrm{P}<0.05)$ increase in egg production (EPR) and egg number (EN) due to feeding laying hen on the diet containing corn (CO) and sunflower oils (SFO). This may be due to the fatty acids profile of these sources as shown in Table (2), especially with the use of isocaloricisonitrogenous diets which almost provided the layers with the sufficient requirements from the essential FAS. These findings agree with the results reported by Attia et al. (2001) who indicated that corn oil treatment showed the better relative increase in EN when compared with the other dietary treatments. On the other hand, El-Gendi et al. (1993) indicated that ration of $8 \%$ CO showed the highest average of EPR for both Dokki and Matrouh layers due to high content of CO from linoleic acid (LA). In contrast, disagreement with that found by El-Husseiny et al. (2002).

On the other hand, the differences in egg weight (EW) and egg mass (EM) values were not significant due to vegetable oil sources. However, corn oil recorded the highest value when compared to other groups These results agreed with the results reported by El-Gendi et al. (1993) who showed that pullets fed on ration supplemented with plant oil increased EW and EM for Dokki 4 laying hens. However, Attia et al. (2001) showed that Co-diet revealed (1.92\%) increase in EW and 19.61\% increase in EM as compared to control diet. On the other hand, this result disagreed with those recorded by Chamruspollert and Sell (1999) and Grobas et al. (1999 a \& b) who reported that egg weight was not improved by addition of either fat or oil to laying hen diets.

Regarding, El-Gendi et al. (1993) results obtained was reported to be due to a specific property of the oils rather than to its energy content. Whereas, Attia et al. (2001) reported that such effects has been attributed to the high linoleic acid (LA) content in $\mathrm{CO}$ and the relatively high content of both linolic acid (LA) and linolenic acid (LNA) in linseed oil (LSO) used in the diet.

However, the addition of kemzyme preparation at $0.05 \%$ of the diet gave the highest values of EPR and EN, during all the experimental periods (Table 4).. These results confirms those of Attia et al. (1997) and Igbasan and Guenter (1997) who reported insignificant increase in EPR and EN due to kemzyme supplementation. On the other hand, Hattaba et al. (1994); Abdel-Wahab (1998); Abd El-Ghany et al. (1997) and Soliman (2003) found that the increase in EPR and EN due to enzyme supplementation was insignificant.

Addition of vitamin $\mathrm{C}$ following kemzyme preparation resulted in the best EW and EM values when compared to the control diet (Table 4). These findings agree with that reported by El-Boushy et al. (1968) and Bell and Marion (1990) who have 
shown remarkable improvement on EW and EM, while, Rowland et al. (1973) showed an opposite trend of V.C. effect on commercial layers hens. Egg weight and egg mass were also increased due to addition of vitamin C in the diet (Soliman, 2003).

No significant differences were found due to the interaction between dietary vegetable oils and treatments supplementation on EPR, EW and EN values.

\section{Feed utilization:}

Data presented in Table (4) show that there were significantly $(\mathrm{P}<0.05)$ effect due to vegetable oil sources. The amount of feed consumed increased significantly $(\mathrm{P}<0.05)$ as a result of vegetable oil added to diets. The average values of feed intake (FI) and feed conversion (FC) showed that the hens fed corn oil diet recorded the highest $(\mathrm{P}<0.05)$ values. The increase in FI may be due to enhanced palatability and physical characteristics of the experimental diets. Moreover, the best FC was found for hens fed diets containing corn oil or sunflower oil. The improvement in feed efficient with oils addition of layer diet in this study may be attributed to more feed consumption and large egg mass. These findings were in agreement with that found by Attia et al. (2001) ; Scragg et al. (1987) ; Grimes et al. (1996) and El-Hussieny et al. (2002). Nevertheless, disagree with the results reported by Vilchez et al. (1990); El-Deek et al. (1988) ; Badawy (1997) ; Baucells et al. (2000).

In general, these results showed that the response of egg performance of laying hens to vegetable oils supplementation could be related to type of oil (Table 2), a specific property of the oil, rather than its energy content, the fatty acid profile, the use of isocaloric- isonitrogenous diets which almost provided the layers with the sufficient requirements from the essential FAs composition of dietary oil content and /or the diets are rich in FAs such as LA and OA. These were themselves highly absorbed and also increase the absorbability of other FAs and related to an increased lipoprotein synthesis by the liver (Vilchez et al., 1990 ; Shutze et al. 1959 and Shutze \& Jensen 1962 ; Marion and Edwards, 1964 ; and Young and Garrett, 1963).

The average values of FI and FC were significantly $(\mathrm{P}<0.05)$ affected by supplemented diets. In general, hens given diet with vitamin $\mathrm{C}$ plus kemzyme preparation gave statistically the lowest value of FI as compared to other treatments. While, kemzyme preparation follow by vitamin $\mathrm{C}$ plus kemzyme preparation gave the best FC value and egg production when compared to the control diet. These results were supported by Sahata and Gillani (1995); Zin Ping Hung et al. (1998) ; AbouZied et al. (2000) and Soliman (2003) reported similar observations for the addition of vitamin $\mathrm{C}$, enzyme mixture or both of them improved feed conversion and egg rate. On the other hand, these reported by Soliman (1997) who found that feed intake and feed conversion of layers were not affected significantly by multi-enzyme supplementation in laying diet.

There is significant $(\mathrm{P}<0.05)$ differences in feed intake and feed conversion due to the interaction effects. Hens fed diet containing corn oil with kemzyme or the combination of vitamin $\mathrm{C}$ plus kemzyme preparation compared to the other treatments. 


\section{Egg quality traits:}

Results in Table (5) show that egg quality traits did not show any significant difference due to vegetable oil sources, except for shell thickness (ST), which was significant $(\mathrm{P}<0.05)$. Duncan multiple range test revealed that vegetable oil sources gave statistically the lowest value of ST as compared to control diet. These findings were found to be in agreement with that found by Attia et al. (2001), they indicated that there is insignificant differences $(\mathrm{P}<0.05)$ between $\mathrm{CO}$ and linseed oil (LSO) treatments in shell thickness (ST). Also, El-Husseiny et al. (2002) indicated that there were no significant differences among dietary lipid sources (fats and oils) in ST. However, most of the egg quality parameters (yolk index or shell (\%) and shell thickness) were significantly $(\mathrm{P}<0.05)$ affected by the treatments supplementation. The addition of vitamin $\mathrm{C}$ and mixture of vitamin $\mathrm{C}$ and kemzyme preparation gave the best values of egg shell quality. The improvement in shell weight and shell thickness due to vitamin C addition was supported by Cheng et al. (1990). Also, Zin Ping Hung et al. (1998) found that diets supplemented with AA at $250 \mathrm{mg} / \mathrm{kg}$ had the best egg shell strength, those with $500 \mathrm{mg} / \mathrm{kg}$ gave the best egg and egg shell quality.

Insignificant effect due to the interaction between vegetable oil sources and treatments supplementation were detected.

\section{Fertility and hatchability:}

Results of fertility and hatchability indicated that there were insignificant differences in groups fed the vegetable oil sources (Table 6). However, it could be seen that the best results in fertility and hatchability are obtained by corn oil or sunflower oil treatments, while the control diet showed the lowest values of the same traits. Chicks weight at hatching was significantly $(\mathrm{P}<0.05)$ effect due to corn oil treatment as compared to other treatments. Similar observation has been noticed by Vilchez et al. (1992) ; Huyghebacrt (1995) and Badawy et al. (1997) who reported that the best results in fertility, hatchability and chick weight at hatch were obtained in palm oil treatment.

The present data in Table (6) showed that treatments supplementation has significant $(\mathrm{P}<0.05)$ effect of fertility $\%$, while the percentage of hatchability were no significant influenced by the same treatments groups. However, the highest values were obtained for a mixture of vitamin $\mathrm{C}$ plus kemzyme preparation as compared to the control group. In addition, supplementing laying hen diets with vitamin $\mathrm{C}$, kemzyme or a mixture of both had significantly $(\mathrm{P}<0.05)$ influence the chick weights at hatch as compared to the control treatment. The improvement in these trait due to vitamin supplementation. These results agrees with that reported by El-Fky (1998) who found beneficial effects of fertility for adding vitamin $\mathrm{C}$ while hatchability percent was decreased as compared to the control group. On the other hand, Madian (2002) who found ascorbic acid supplementation significant increased fertility percent. Abdel-Galil and Abdel-Samad (2003) indicated that supplementing vitamin C improved hatchability and fertility percentages for both Dokki4 and Bandara egg than control and also increased hatched-chick weight more than other groups. While, Attia et al. (1997) who found that hatchability percentage of total or fertile eggs was not 
Table (5): Effect of dietary vegetable oils and some feed additives and their interaction between them on egg quality traits.

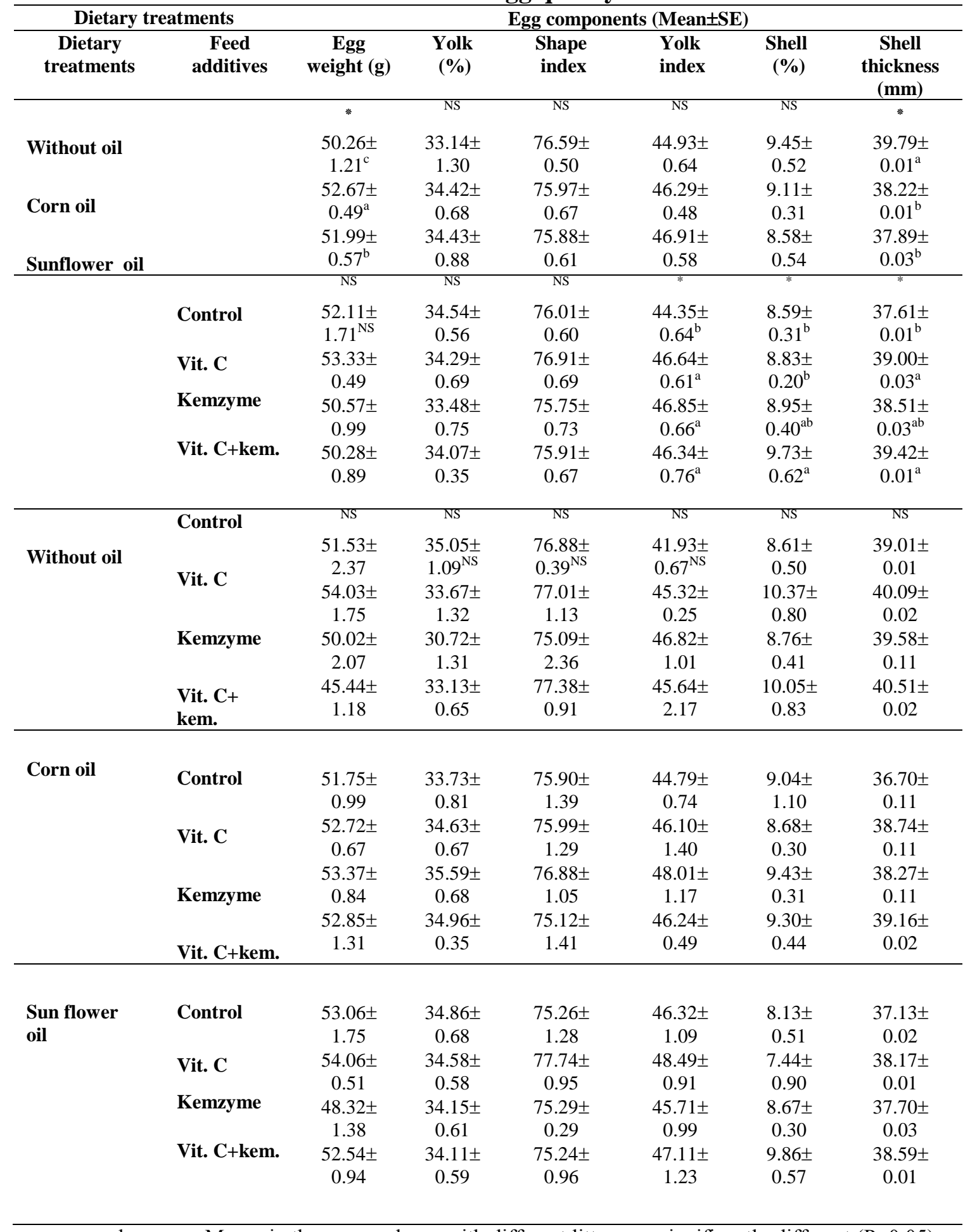

$\mathrm{a}, \mathrm{b}, \mathrm{c} \ldots . . \mathrm{e}:$ Means in the same column with different litters are significantly different $(\mathrm{P}<0.05)$. 
Table (6): Effect of dietary vegetable oils and some feed additives and their interaction between them on fertility hatchability and chicks weight of laying hens.

\begin{tabular}{|c|c|c|c|c|c|}
\hline \multicolumn{2}{|c|}{ Dietary treatments } & \multicolumn{4}{|c|}{ Mean $\pm S E$} \\
\hline \multirow{2}{*}{$\begin{array}{c}\text { Dietary } \\
\text { treatments }\end{array}$} & \multirow{2}{*}{$\begin{array}{c}\text { Feed } \\
\text { additives }\end{array}$} & \multirow{2}{*}{$\begin{array}{l}\text { Fertility } \\
(\%)\end{array}$} & \multicolumn{2}{|c|}{ Hatchability from } & \multirow{2}{*}{$\begin{array}{c}\text { Chicks } \\
\text { weight (g) }\end{array}$} \\
\hline & & & Fertile egg & Total egg & \\
\hline \multirow[b]{2}{*}{ Without oil } & & NS & NS & NS & $*$ \\
\hline & & $\begin{array}{c}86.96 \pm \\
0.36\end{array}$ & $\begin{array}{c}73.68 \pm \\
1.22\end{array}$ & $\begin{array}{c}66.92 \pm \\
0.74\end{array}$ & $\begin{array}{c}33.60 \pm \\
0.16 \mathrm{~b}\end{array}$ \\
\hline Corn oil & & $\begin{array}{c}87.32 \pm \\
0.34\end{array}$ & $\begin{array}{c}73.99 \pm \\
1.27\end{array}$ & $\begin{array}{c}67.21 \pm \\
0.77\end{array}$ & $\begin{array}{c}34.04 \pm \\
0.12 \mathrm{a}\end{array}$ \\
\hline \multirow[t]{6}{*}{ Sunflower oil } & & $\begin{array}{c}87.42 \pm \\
0.35\end{array}$ & $\begin{array}{c}74.08 \pm \\
1.30\end{array}$ & $\begin{array}{c}67.20 \pm \\
0.78\end{array}$ & $\begin{array}{c}33.42 \pm \\
0.13 b\end{array}$ \\
\hline & & $*$ & $\mathbf{N S}$ & $\mathbf{N S}$ & $*$ \\
\hline & Control & $\begin{array}{c}86.26 \pm \\
0.33 b\end{array}$ & $\begin{array}{l}73.11 \pm \\
1.48 \mathrm{NS}\end{array}$ & $\begin{array}{c}66.41 \pm \\
0.89 \mathrm{NS}\end{array}$ & $\begin{array}{l}33.72 \pm \\
0.18 \mathrm{ab}\end{array}$ \\
\hline & Vit. C & $\begin{array}{l}87.74 \pm \\
0.32 \mathrm{ab}\end{array}$ & $\begin{array}{c}74.36 \pm \\
1.49\end{array}$ & $\begin{array}{c}67.54 \pm \\
0.91\end{array}$ & $\begin{array}{c}34.03 \pm \\
0.15 \mathrm{a}\end{array}$ \\
\hline & Kemzyme & $\begin{array}{c}86.69 \pm \\
0.32 b\end{array}$ & $\begin{array}{c}73.46 \pm \\
1.48\end{array}$ & $\begin{array}{c}66.61 \pm \\
0.86\end{array}$ & $\begin{array}{c}33.54 \pm \\
0.18 \mathrm{~b}\end{array}$ \\
\hline & Vit. C+kem. & $\begin{array}{c}88.20 \pm \\
0.30 \mathrm{a}\end{array}$ & $\begin{array}{c}74.73 \pm \\
1.42\end{array}$ & $\begin{array}{c}67.88 \pm \\
0.84\end{array}$ & $\begin{array}{c}33.44 \pm \\
0.16 \mathrm{~b}\end{array}$ \\
\hline \multirow[t]{5}{*}{ Without oil } & & NS & NS & NS & NS \\
\hline & Control & $\begin{array}{c}85.92 \pm \\
0.64\end{array}$ & $\begin{array}{c}2.81 \pm \\
2.94\end{array}$ & $\begin{array}{c}66.13 \pm \\
1.78\end{array}$ & $\begin{array}{c}33.72 \pm \\
0.23\end{array}$ \\
\hline & Vit. $\mathrm{C}$ & $\begin{array}{c}87.44 \pm \\
0.64\end{array}$ & $\begin{array}{c}74.09 \pm \\
2.98\end{array}$ & $\begin{array}{c}67.30 \pm \\
1.81\end{array}$ & $\begin{array}{c}34.33 \pm \\
0.23\end{array}$ \\
\hline & Kemzyme & $\begin{array}{c}86.32 \pm \\
0.64\end{array}$ & $\begin{array}{c}73.15 \pm \\
2.95\end{array}$ & $\begin{array}{c}66.44 \pm \\
1.78\end{array}$ & $\begin{array}{c}33.46 \pm \\
0.23\end{array}$ \\
\hline & Vit. C+kem. & $\begin{array}{c}88.16 \pm \\
0.32 \\
\end{array}$ & $\begin{array}{c}74.66 \pm \\
2.36 \\
\end{array}$ & $\begin{array}{c}67.64 \pm \\
1.29 \\
\end{array}$ & $\begin{array}{c}32.99 \pm \\
0.23 \\
\end{array}$ \\
\hline \multirow[t]{4}{*}{ Corn oil } & Control & $\begin{array}{c}86.41 \pm \\
0.64\end{array}$ & $\begin{array}{c}73.22 \pm \\
2.95\end{array}$ & $\begin{array}{c}66.51 \pm \\
1.79\end{array}$ & $\begin{array}{c}34.21 \pm \\
0.22\end{array}$ \\
\hline & Vit. C & $\begin{array}{c}87.82 \pm \\
0.59\end{array}$ & $\begin{array}{c}74.41 \pm \\
2.96\end{array}$ & $\begin{array}{c}67.59 \pm \\
1.77\end{array}$ & $\begin{array}{c}34.23 \pm \\
0.23\end{array}$ \\
\hline & Kemzyme & $\begin{array}{c}86.81 \pm \\
0.64\end{array}$ & $\begin{array}{c}73.56 \pm \\
2.97\end{array}$ & $\begin{array}{c}66.81 \pm \\
1.79\end{array}$ & $\begin{array}{c}34.06 \pm \\
0.23\end{array}$ \\
\hline & Vit. C+kem. & $\begin{array}{c}88.22 \pm \\
0.59\end{array}$ & $\begin{array}{c}74.76 \pm \\
2.97\end{array}$ & $\begin{array}{c}67.91 \pm \\
1.77\end{array}$ & $\begin{array}{c}33.63 \pm \\
0.23\end{array}$ \\
\hline \multirow[t]{4}{*}{ Sun flower oil } & Control & $\begin{array}{c}86.52 \pm \\
0.64\end{array}$ & $\begin{array}{c}73.22 \pm \\
2.96\end{array}$ & $\begin{array}{c}66.59 \pm \\
1.79\end{array}$ & $\begin{array}{c}33.23 \pm \\
0.23\end{array}$ \\
\hline & Vit. C & $\begin{array}{c}87.96 \pm \\
0.64\end{array}$ & $\begin{array}{c}74.56 \pm \\
3.03\end{array}$ & $\begin{array}{c}67.73 \pm \\
1.83\end{array}$ & $\begin{array}{c}33.65 \pm \\
0.23\end{array}$ \\
\hline & Kemzyme & $\begin{array}{c}86.95 \pm \\
0.60\end{array}$ & $\begin{array}{c}73.69 \pm \\
2.94\end{array}$ & $\begin{array}{c}66.57 \pm \\
1.56\end{array}$ & $\begin{array}{c}33.10 \pm \\
0.22\end{array}$ \\
\hline & Vit. C+kem. & $\begin{array}{c}88.22 \pm \\
0.79\end{array}$ & $\begin{array}{c}74.76 \pm \\
3.13\end{array}$ & $\begin{array}{c}67.91 \pm \\
1.93\end{array}$ & $\begin{array}{c}33.44 \pm \\
0.16\end{array}$ \\
\hline
\end{tabular}

$\mathrm{a}, \mathrm{b}, \mathrm{c} \ldots . . \mathrm{e}$ : Means in the same column with different litters are significantly different $(\mathrm{P}<0.05)$. 
influenced by kemzyme additions. Brake (1992) who found no adverse effect for kemzyme addition on fertility of broiler breeder hens eggs.

Results obtained indicated that fertility and hatchability traits were not affected significantly by interaction effect.

\section{Blood constituents:}

Results Table (7) showed that the vegetable oil sources increased significantly $(\mathrm{P}<0.05)$ values of serum cholesterol or yolk cholesterol and there were insignificantly values of total serum lipids when compared to the control diet. In this regard, Kalanithi and Badri (1994) and Grashom (1994) reported that when laying hens were fed on diets supplemented with vegetable oil up to $8 \%$, total serum lipids and cholesterol levels were elevated compared with control diet. On the contrary to the results of this study, Maurice and Jensen (1978) reported that there were no significant differences in total plasma lipids and cholesterol values among diets supplemented with 3.3 or $7 \%$ vegetable oil comparing to control diet (without supplementation oil).

Analysis of variance for serum calcium and phosphors content indicated that the difference among vegetable oil sources the experimental treatments were not significant. Similar trend was observed by El-Komey and Hamouda (1996).

On the other hand, the values of total cholesterol and lipid significantly decreased especially with vitamin $\mathrm{C}$ plus kemzyme preparation addition comparing with the control diet. The best value of serum calcium of laying hens in the present experiment showed almost a similar trend to the phosphorus content due to vitamin $\mathrm{C}$ plus kemzyme preparation supplemented. The reduction effect on serum cholesterol and total lipid has been reported by many workers (Takahashi and Jensen, 1985 ; Takahashi and Horignchi, 1991 and Hedaya and Korshom, 1993). These results of the aforementioned author are in harmony with the current results, which showed that plasma cholesterol and total lipid level decreased significantly $(\mathrm{P}<0.01)$ with increasing the level of vitamin C from 0.0 up to $300 \mathrm{mg} / \mathrm{L}$. El-Deek et al. (2003) found that there was unexplained decreased in serum cholesterol of hens fed 0 and $60 \%$ barely containing diets when enzyme was added. Ghazalah et al. (1994) who found that most blood parameters were insignificantly different in chicks supplemented with kemzyme.

Results in Table (7) show that the lowest value of total cholesterol and lipids due to the interaction effect between the diet without vegetable oil source and those supplemented with vitamin $\mathrm{C}$ plus kemzyme preparation, while the highest value of calcium and phosphorus content obtained by the interaction effect between vegetable oil source and vitamin $\mathrm{C}$ plus kemzyme preparation diets.

\section{Yolk cholesterol:}

Data in Table (7) show that the diet containing sunflower oil recorded significantly higher value compared to the control diet. These results agree with obtained by Weiss et al. (1964) who reported that feeding of either sunflower oil or linseed oil at $3 \%$ of the diet to laying hens increased the yolk cholesterol, whereas 
Table (7): Effect of dietary vegetable oils and some feed additives and their interaction between them on blood constituents and yolk cholesterol.

\begin{tabular}{|c|c|c|c|c|c|c|}
\hline \multicolumn{2}{|c|}{ Dietary treatments } & \multicolumn{5}{|c|}{ Mean \pm SE } \\
\hline $\begin{array}{c}\text { Dietary } \\
\text { treatments }\end{array}$ & $\begin{array}{c}\text { Feed } \\
\text { additives }\end{array}$ & $\begin{array}{c}\text { Total lipids } \\
(\mathrm{g} / \mathrm{L})\end{array}$ & $\begin{array}{r}\text { Cholesterol } \\
(\mathrm{mg} / 100 \mathrm{ml})\end{array}$ & $\begin{array}{c}\text { Yolk } \\
\text { cholesterol } \\
\text { (mg/mg/yol } \\
\text { k) }\end{array}$ & $\begin{array}{l}\text { Calcium } \\
(\mathrm{mg} / \mathrm{dL})\end{array}$ & $\begin{array}{c}\text { Phosphorus } \\
\text { (mg/dL) }\end{array}$ \\
\hline & & $*$ & $*$ & $*$ & $*$ & $*$ \\
\hline Without oil & & $\begin{array}{l}15.83 \pm \\
0.31^{\mathrm{NS}}\end{array}$ & $\begin{array}{c}122.86 \pm \\
0.77^{\mathrm{b}}\end{array}$ & $\begin{array}{c}16.10 \pm \\
0.11^{\mathrm{c}}\end{array}$ & $\begin{array}{l}7.19 \pm \\
0.07^{\mathrm{NS}}\end{array}$ & $\begin{array}{l}3.75 \pm \\
0.03^{\mathrm{NS}}\end{array}$ \\
\hline Corn oil & & $\begin{array}{c}16.46 \pm \\
0.31\end{array}$ & $\begin{array}{c}126.18 \pm \\
0.85^{\mathrm{ab}}\end{array}$ & $\begin{array}{c}17.08 \pm \\
0.12^{\mathrm{b}}\end{array}$ & $\begin{array}{c}7.27 \pm \\
0.06\end{array}$ & $\begin{array}{c}3.69 \pm \\
0.02\end{array}$ \\
\hline $\begin{array}{c}\text { Sunflower } \\
\text { oil }\end{array}$ & & $\begin{array}{c}17.78 \pm \\
0.37\end{array}$ & $\begin{array}{c}131.21 \pm \\
0.87^{\mathrm{a}}\end{array}$ & $\begin{array}{c}17.74 \pm \\
0.12^{\mathrm{a}}\end{array}$ & $\begin{array}{l}7.28 \pm \\
0.07\end{array}$ & $\begin{array}{c}3.71 \pm \\
0.02\end{array}$ \\
\hline & & $*$ & $*$ & $*$ & $*$ & $*$ \\
\hline & Control & $\begin{array}{l}18.43 \pm \\
0.42^{\mathrm{NS}}\end{array}$ & $\begin{array}{c}146.46 \pm \\
0.59^{\mathrm{a}}\end{array}$ & $\begin{array}{c}19.67 \pm \\
0.09^{\mathrm{a}}\end{array}$ & $\begin{array}{l}6.14 \pm \\
0.07^{b}\end{array}$ & $\begin{array}{l}3.68 \pm \\
0.03^{\mathrm{ab}}\end{array}$ \\
\hline & Vit. C & $\begin{array}{c}17.26 \pm \\
0.43\end{array}$ & $\begin{array}{c}124.00 \pm \\
0.63^{\mathrm{b}}\end{array}$ & $\begin{array}{c}16.84 \pm \\
0.10^{\mathrm{b}}\end{array}$ & $\begin{array}{l}7.22 \pm \\
0.07^{\mathrm{a}}\end{array}$ & $\begin{array}{l}3.99 \pm \\
0.04^{\mathrm{a}}\end{array}$ \\
\hline & Kemzyme & $\begin{array}{c}15.89 \pm \\
0.51\end{array}$ & $\begin{array}{c}118.69 \pm \\
0.51^{\mathrm{bc}}\end{array}$ & $\begin{array}{c}15.81 \pm \\
0.08^{\mathrm{c}}\end{array}$ & $\begin{array}{l}7.76 \pm \\
0.06^{\mathrm{a}}\end{array}$ & $\begin{array}{l}3.44 \pm \\
0.03^{b}\end{array}$ \\
\hline & Vit. C+kem. & $\begin{array}{c}15.19 \pm \\
0.42\end{array}$ & $\begin{array}{c}117.83 \pm \\
0.46^{\mathrm{c}}\end{array}$ & $\begin{array}{c}15.57 \pm \\
0.07^{\mathrm{c}}\end{array}$ & $\begin{array}{l}7.85 \pm \\
0.06^{\mathrm{a}}\end{array}$ & $\begin{array}{l}3.76 \pm \\
0.02^{\mathrm{ab}}\end{array}$ \\
\hline & & NS & $*$ & $*$ & $*$ & $*$ \\
\hline Without oil & Control & $\begin{array}{c}17.84 \pm \\
1.37\end{array}$ & $\begin{array}{c}141.03 \pm \\
1.54^{\mathrm{abc}}\end{array}$ & $\begin{array}{c}18.57 \pm \\
0.21^{\mathrm{b}}\end{array}$ & $\begin{array}{l}6.20 \pm \\
0.23^{b}\end{array}$ & $\begin{array}{c}3.66 \pm \\
0.10\end{array}$ \\
\hline & Vit. C & $\begin{array}{c}15.64 \pm \\
1.36\end{array}$ & $\begin{array}{c}119.36 \pm \\
1.41^{\mathrm{bc}}\end{array}$ & $\begin{array}{l}15.77 \pm \\
0.22^{\text {def }}\end{array}$ & $\begin{array}{l}7.11 \pm \\
0.22^{\mathrm{ab}}\end{array}$ & $\begin{array}{c}4.36 \pm \\
0.10\end{array}$ \\
\hline & Kemzyme & $\begin{array}{c}14.73 \pm \\
1.36\end{array}$ & $\begin{array}{c}115.77 \pm \\
1.46^{\mathrm{c}}\end{array}$ & $\begin{array}{c}15.18 \pm \\
0.21^{\text {ef }}\end{array}$ & $\begin{array}{l}7.67 \pm \\
0.22^{\mathrm{a}}\end{array}$ & $\begin{array}{c}3.29 \pm \\
0.10\end{array}$ \\
\hline & Vit. C+kem. & $\begin{array}{c}15.13 \pm \\
1.36 \\
\end{array}$ & $\begin{array}{c}115.29 \pm \\
1.47^{\mathrm{c}} \\
\end{array}$ & $\begin{array}{c}14.88 \pm \\
0.22^{\mathrm{f}} \\
\end{array}$ & $\begin{array}{l}7.78 \pm \\
0.24^{\mathrm{a}} \\
\end{array}$ & $\begin{array}{c}3.71 \pm \\
0.09 \\
\end{array}$ \\
\hline Corn oil & Control & $\begin{array}{c}18.36 \pm \\
1.36\end{array}$ & $\begin{array}{c}147.08 \pm \\
1.55^{\mathrm{ab}}\end{array}$ & $\begin{array}{c}19.88 \pm \\
0.22^{\mathrm{a}}\end{array}$ & $\begin{array}{l}6.11 \pm \\
0.22^{\mathrm{b}}\end{array}$ & $\begin{array}{c}3.72 \pm \\
0.09\end{array}$ \\
\hline & Vit. C & $\begin{array}{c}16.73 \pm \\
1.37\end{array}$ & $\begin{array}{c}121.49 \pm \\
1.42^{\mathrm{bc}}\end{array}$ & $\begin{array}{c}16.87 \pm \\
0.22^{\text {cd }}\end{array}$ & $\begin{array}{l}7.22 \pm \\
0.23^{\mathrm{ab}}\end{array}$ & $\begin{array}{c}3.87 \pm \\
0.09\end{array}$ \\
\hline & Kemzyme & $\begin{array}{c}15.64 \pm \\
1.38\end{array}$ & $\begin{array}{c}118.43 \pm \\
1.10^{\mathrm{bc}}\end{array}$ & $\begin{array}{l}15.78 \pm \\
0.22^{\text {def }}\end{array}$ & $\begin{array}{l}7.78 \pm \\
0.23^{\mathrm{a}}\end{array}$ & $\begin{array}{c}3.11 \pm \\
0.09\end{array}$ \\
\hline & Vit. C+kem. & $\begin{array}{c}15.14 \pm \\
1.38 \\
\end{array}$ & $\begin{array}{c}117.69 \pm \\
1.42^{\mathrm{bc}}\end{array}$ & $\begin{array}{l}15.76 \pm \\
0.20^{\operatorname{def}}\end{array}$ & $\begin{array}{l}7.89 \pm \\
0.23^{\mathrm{a}} \\
\end{array}$ & $\begin{array}{c}3.70 \pm \\
0.09 \\
\end{array}$ \\
\hline Sun flower & Control & $\begin{array}{c}19.11 \pm \\
1.42\end{array}$ & $\begin{array}{c}151.27 \pm \\
1.55^{\mathrm{a}}\end{array}$ & $\begin{array}{c}20.55 \pm \\
0.20^{\mathrm{a}}\end{array}$ & $\begin{array}{l}6.10 \pm \\
0.23^{b}\end{array}$ & $\begin{array}{c}3.69 \pm \\
0.09\end{array}$ \\
\hline oil & Vit. C & $\begin{array}{c}19.14 \pm \\
1.38\end{array}$ & $\begin{array}{c}131.16 \pm \\
1.55^{\mathrm{abc}}\end{array}$ & $\begin{array}{c}17.87 \pm \\
0.21^{\mathrm{ab}}\end{array}$ & $\begin{array}{l}7.32 \pm \\
0.24^{\mathrm{ab}}\end{array}$ & $\begin{array}{c}3.76 \pm \\
0.09\end{array}$ \\
\hline & Kemzyme & $\begin{array}{c}17.31 \pm \\
2.11\end{array}$ & $\begin{array}{c}121.87 \pm \\
1.73^{\mathrm{bc}}\end{array}$ & $\begin{array}{c}16.47 \pm \\
0.21^{\mathrm{de}}\end{array}$ & $\begin{array}{l}7.82 \pm \\
0.24^{\mathrm{a}}\end{array}$ & $\begin{array}{c}3.56 \pm \\
0.09\end{array}$ \\
\hline & Vit. C+kem. & $\begin{array}{c}15.31 \pm \\
2.11\end{array}$ & $\begin{array}{c}120.52 \pm \\
1.31^{\mathrm{bc}}\end{array}$ & $\begin{array}{l}16.08 \pm \\
0.21^{\mathrm{def}}\end{array}$ & $\begin{array}{l}7.87 \pm \\
0.24^{\mathrm{a}}\end{array}$ & $\begin{array}{c}3.86 \pm \\
0.10\end{array}$ \\
\hline
\end{tabular}


soybean oil had no significant effect. El-Deek et al. (1988) indicated that diet containing 4\% oil resulted in an increase in the amount of cholesterol compared to the other two dietary treatments.

From Table (7) it is noticed that the addition of vitamin $\mathrm{C}$ plus kemzyme preparation decreased yolk cholesterol compared to hens fed the control diet without addition. These results can be explained by the results of Aidukonene and Kidguolene (1988) who found that supplementation of enzyme preparation to the broiler diets decreased concentrations of cholesterol in broiler blood serum. Also, Pettersson and Aman (1992) who found with oat bran diet, the enzyme supplementation decreased serum cholesterol concentrations.

The interaction effect between diet without any vegetable oil with vitamin $\mathrm{C}$ plus kemzyme preparation gave the lowest value of yolk cholesterol compared to the other treatments (Table 7).

\section{Economic evaluation:}

It was observed that the sunflower diet recorded the highest (best) NR (0.95 pt) and EE (5.38\%) follow by, corn oil gave NR (0.82 pt) and EE (4.48\%) when comparing to control diet (Table 8). Generally, it was found that, the use of oils in supplementing layer diets improved $\mathrm{NR}$ and EE\% as compared to the nonsupplemented diet (control diet).

On the other hand, kemzyme preparation recorded the highest (best) NR (1.47) and $\mathrm{EE}(7.79 \%)$ follow by the combination of vitamin $\mathrm{C}$ and kemzyme preparation gave NR (0.86 pt) and EE (4.94\%) when compared to the other treatment supplementation.

In conclusion, these results of this study indicated that feeding laying hens on diets containing sunflower oil only at $3 \%$ of the diet or corn oils supplements with kemzyme preparation improved the performance of laying hen and economical efficiency especially, at the late stage of egg production.

\section{REFERENCES}

Abdel-Ghani, A. E. ; S. A. Ibrahim ; E. H. El-Ganzory amd A. I. El-Faham (1997). Influence of Isoforte and enzyme preparation. pp 79-89. $2^{\text {nd }}$ Hungrian Egyptian Poultry Conference, 16-19 Sept. 1997, Godallo, Hungary.

Abdel-Galil, A. and M. H. Abdel-Samad (2003). Effect of vitamin E, C, selenium and zinc supplementation on reproductive and performance of two local breeds of chickens under hot climate condition. Egypt. Poult., 24: 217-229.

Abde-Wahab, H. M. (1998). The use of sorghum or rice bran in broiler and layer diets with references to enzyme supplementation. Ph. D. Thesis, Fac. of Agric. Fayoum, Cairo Univ., Egypt.

Abou-Zeid, A. E. ; N. S. Isshak ; Neamat A. Badaway and Naglaa Abou Ouf (2000). The potential effect of vitamin C supplementation in quail. Egypt. Poult. Sci., 20: 817-838. 
Table (8): Effect of dietary vegetable oils and some feed additives and their interaction between them on egg quality traits.

\begin{tabular}{|c|c|c|c|c|c|c|c|c|}
\hline \multicolumn{2}{|c|}{ Dietary treatments } & \multirow{2}{*}{$\begin{array}{l}\text { Total feed } \\
\text { intake } \\
\text { /hen (kg) }\end{array}$} & \multirow{2}{*}{$\begin{array}{c}\text { Total feed } \\
\text { cost/hen } \\
(\mathrm{L} / \mathrm{E}) \\
\end{array}$} & \multirow{2}{*}{$\begin{array}{c}\text { Total egg } \\
\text { number/hen }\end{array}$} & \multirow{2}{*}{$\begin{array}{c}\text { Total egg } \\
\text { price/hen } \\
\text { (LE) }\end{array}$} & \multirow{2}{*}{$\begin{array}{c}\text { Net } \\
\text { revenue } \\
\text { /hen (LE) }\end{array}$} & \multirow{2}{*}{$\begin{array}{c}\text { Economic } \\
\text { efficiency } \\
(\%)\end{array}$} & \multirow{2}{*}{$\begin{array}{c}\text { Relative } \\
\text { to control } \\
\%)\end{array}$} \\
\hline $\begin{array}{c}\text { Dietary } \\
\text { treatments }\end{array}$ & $\begin{array}{c}\text { Feed } \\
\text { additives }\end{array}$ & & & & & & & \\
\hline Without oil & & 14.08 & 15.62 & 43.92 & 16.25 & 0.68 & 4.15 & 140.84 \\
\hline Corn oil & & 14.21 & 17.19 & 48.68 & 18.01 & 0.86 & 4.76 & 161.43 \\
\hline \multirow{5}{*}{$\begin{array}{l}\text { Sunflower } \\
\text { oil }\end{array}$} & & 14.16 & 16.42 & 46.95 & 17.37 & 1.02 & 5.87 & 196.09 \\
\hline & Control & 14.41 & 16.57 & 46.96 & 17.37 & 0.80 & 4.55 & 154.23 \\
\hline & Vit. C & 14.20 & 16.47 & 44.92 & 16.62 & 0.45 & 2.32 & 78.52 \\
\hline & Kemzyme & 14.11 & 16.36 & 47.98 & 17.75 & 1.39 & 7.79 & 264.29 \\
\hline & $\begin{array}{l}\text { Vit. C } \\
\text { +kem. }\end{array}$ & 13.88 & 16.24 & 46.20 & 17.09 & 0.86 & 4.94 & 167.45 \\
\hline \multirow[t]{4}{*}{ Without oil } & Control & 14.34 & 15.77 & 43.92 & 16.25 & 0.48 & 2.95 & 100.00 \\
\hline & Vit. C & 14.14 & 15.44 & 42.72 & 15.81 & 0.37 & 2.34 & 79.32 \\
\hline & Kemzyme & 14.04 & 15.58 & 46.08 & 17.05 & 1.47 & 8.62 & 292.20 \\
\hline & $\begin{array}{l}\text { Vit. C } \\
\text { +kem. }\end{array}$ & 13.82 & 15.47 & 42.96 & 15.90 & 0.43 & 2.71 & 91.86 \\
\hline \multirow[t]{4}{*}{ Corn oil } & Control & 14.52 & 17.42 & 48.52 & 17.95 & 0.53 & 2.95 & 100.00 \\
\hline & Vit. C & 14.25 & 17.04 & 47.24 & 17.48 & 0.44 & 2.52 & 85.42 \\
\hline & Kemzyme & 14.15 & 17.12 & 50.88 & 18.83 & 1.71 & 9.08 & 307.79 \\
\hline & $\begin{array}{l}\text { Vit. C } \\
\text { +kem. }\end{array}$ & 13.93 & 16.99 & 48.08 & 17.79 & 0.80 & 4.50 & 152.54 \\
\hline \multirow{4}{*}{$\begin{array}{c}\text { Sun flower } \\
\text { oil }\end{array}$} & Control & 14.38 & 16.53 & 48.44 & 17.92 & 1.39 & 7.75 & 262.71 \\
\hline & Vit. C & 14.23 & 16.24 & 44.80 & 16.58 & 0.34 & 2.09 & 70.84 \\
\hline & Kemzyme & 14.14 & 16.40 & 47.00 & 17.39 & 0.99 & 5.69 & 192.88 \\
\hline & $\begin{array}{l}\text { Vit. C } \\
\text { +kem. }\end{array}$ & 13.90 & 16.26 & 47.56 & 17.60 & 1.34 & 7.61 & 25796 \\
\hline
\end{tabular}

$\mathrm{a}, \mathrm{b}, \mathrm{c} \ldots . . \mathrm{e}$ : Means in the same column with different litters are significantly different $(\mathrm{P}<0.05)$. 
Aidukonene, B. and V. Kidguolene (1988). Effect of enzyme preparations Iysozyme G3 $\mathrm{x}$ on physiological and biochemical values of blood in broiler chickens. Nutr. Abst. and Rev., 59 Abs. 3377.

Amer, (1977). Effect of fats source and level on the body composition of broiler and laying hens and the cholesterol content of egg and plasma. Ph. D. Thesis, Fac. of Agric., Movisad Univ., Egypt.

A.O.A.C. (1994). Association Official Analytical Chemists. Official Method of Analysis. $16^{\text {th }}$ ed. Published by the A.O.A.C. Washington, D.C.

Attia, M. Y. ; M. A. Abou El-Ella ; G. A. Abd-Allah ; M. A. Breika and H. M. Fayck (2001). Effect of using animal fat, corn oil or linseed oil in Matrouh layer diets. $2^{\text {nd }}$ International Conference on Animal Pro. \& Health in Semi-Arid Areas, El-Arisj, North Sinai, Egypt.

Attia, Y. A. ; A. I. Abd El-Ghani ; E. H. El-Gnazory and S. B. Abd El-Hady (1997). Responses of Bandarah local breed to some pro-nutrient addition. Egypt. Poulrty Sci., 17(II): 1-22.

Badawy, N. A. (1997). Influence of dietary oil on performance blood lipids and immunoresponse of Japanese quail. Egypt. Pout. Sci., 17(II): 53-75.

Baucells, M. D. ; N. Crespo ; A. C. Barroeta ; S. Lopez-Ferrer and M. A. Grashorn (2000). Incorporation of different polyunsaturated fatty acids into eggs. Poult. Sci., 79: $51-59$.

Bell, D. E. and Marion, J. E. (1990). Vitamin C in laying hen diets. Poult. Sci., 69: 19001904.

Bedford, M. R. (1997). Factors affecting responses of wheat based diets to enzyme supplementation. In: Rec. Adv. in Anim. Nutr. in Aust., 11: 1-7.

Brake, J. T. (1992). Egg production of broiler breeders increases when fed diets containing commercial enzyme preparations-possible method to improve performance in hot climates. Proc. $19^{\text {th }}$ World's Poultry Congress Amsterdam Sept., 1992.

Chamruspollert, M. and J. L. Sell (1999). Transfer of dietary conjugated linoleic acid to egg yolks of chickens. Poult. Sci., 78: 1138-1150.

Cheng, T. K. ; C. N. Coon and M. I. Homre (1990). Effect of environmental stress on the ascorbic acid requirements of laying hens. Poult. Sci., 69: 774-780.

Duncan, D. B. (1955). Multiple range and multiple F-test. Biometrics, 11:1-42.

El-Boushy, A. R. ; P. C. M. Jimons ; G. Wierlz (1968). Structure and ultra-structure of the hens egg as influenced by addition. Poult. Sci., 47:456-467.

El-Deek, A. A. ; M. A. Aser ; Y. A. Attia and Soliman Amal A. (2003). Productivity of broiler breeder hens when fed practical or vegetable diets containing high levels of barley, sunflower meal or barley and sunflower meal without or with enzyme mixture supplementation. I-Barley. Egypt Poult. Sci., 23(I): 239-257.

El-Deek, A. A. ; M. A. Kosba ; M. Farghaly and Y. Affi (1988). Performance of laying peelers fed different levels of cotton seed oil at various ages. Egypt. Poult. Sci., 8: 324-354.

El-Fiky, A. A. (1998). Addition of ascorbic acid to relieve the adverse effects of using under ground and saline water on egg quality and some physiological parameters. Egypt. Poult. Sci., 18(1): 81-101. 
El-Gendi, G. M. ; N. Y. Abdel-Malak and M. M. Karousa (1993). Performance of laying pullets fed different levels of cotton seed oil at various ages. Egypt. Poult. Sci., 8: 324-354.

El-Husseiny, O. M. ; A. Z. Soliman ; M. O. Abd El-Samee and I. I. Omara (2002). Influence of dietary lipid sources and levels on laying hen performance, egg quality and nutrient utilization. Egypt. Poult. Sci., 22: (III): 763-791.

El-Komey, A. G. and I. Homouda (1996). Effects of Aspirin and corn oil on growth performance and blood composition of weaned New Zealand White rabbits. Egypt. Poult. Sci., 16(I): 155-170.

El-Wardany, A. M. ; L. M. Gohar and A. A. Enab (1994). Effect of bred laying period and selection for egg weight on egg quality in two local breed of chickens. Egypt. Poult. Sci., 14:23-49.

Ghazalah, A. A. ; O. M. El-Husseiny ; H. M. Fayek and S. Abou El-Wafa (1994). Influence of enzyme proportions and growth parameters on broiler performance. The $2^{\text {nd }}$ Scientific Conference on Poultry, Kafr El-Sheikh, Egypt. 140-165.

Grashorn, M. A. (1994). Influence of different fat sources on cholesterol in blood and yolk of laying hens. Archiv-Fur-Geflugelkude, 58: 224-231.

Grimes, J. L. ; D. V. Mourice ; S. F. Lightseg and T. G. Gay Lord (1996). Dietary grilled fat and layer chicken performance and egg composition. Poult. Sci., 75: 250-253.

Grobas, S. ; J. Mendez ; C. De Blas and G. G. Mateos (1999 a). Influence of dietary energy, supplemental fat and linoleic acid concentrations on performance of laying hens at two ages. Poult. Sci., 40: 681-687.

Grobas, S. ; J. Mendez ; C. De Blas and G. G. Mateos (1999b). Laying hen productivity as affected by energy supplemented fat and linoleic acid concentration of the diet. Poult. Sci., 78: 1542-1551.

Hakansson, J. (1975). The effect of fat on the retention of calcium phosphorus and magnesium in laying hens. Swedish J. Agric. Res., 5: 39.

Hattaba, N. A. ; S. A. Ibrahim ; A. L. El-Faham and M. A. El-Sheikh (1994). Utilization of the enzyme preparation "kemzyme" in layer rations. The $2^{\text {nd }}$ Scientific Conference on Poultry, Kafr El-Sheikh, Egypt.

Hedaya and M. Korshom (1993). Effect of ascorbic acid supplementation on some biochemical and haematological parameters in broiler chickens. Bani Seuf Vet. Med. Res., Vol. 111 (2) July, 1992.

Huyghebacrt, G. (1995). In corporation of polyunsaturated fatty acids in egg yolk fat at varying dietary fat levels and composition. Arch. Geflueglek, 59(2): 145-152.

Igbasan, F. A. and Guenter, W. (1997). The influence of microziation Dehulling and enzyme supplementation on the nutritional value of peas for laying hens. Poult. Sci., 76: 331-337.

Jensen, L. S. ; J. B. Allred ; R. E. Fry and J. Meginnis (1958). Evidence for an unidenbified factor necessary for maximum egg weight in chickens. J. Nur., 65: 219-233.

Kalanithi, N. and M. Badri (1994). Selected reading on palm oil and its uses. $1^{\text {st }}$ Ed. pasteurized. 151-159. Palm oil Research Institute of Malysia Ministry of Primary Industries, Malysia. Po. Box. 10620, 50720 Kuala Lampur, Malaysia. 
Katongole, J. B. D. and B. E. March (1980). Fat utilization in relation to intestinal fatty acid binding protein and bile salts in chick of different ages and different genetic sources. Poult. Sci., 59: 819-827.

Marion, J. E. and H. M. Edwards (1964). The response of laying hens to dietary oils and purified fatty acids. Poult. Sci., 43: 911-918.

Marsman, G. J. ; H. Gruppen ; A. F. B. Von Der Pool ; R. P. Kwakkel ; M. W. A. Verstegen and A. G. J. Voragen (1997). The effect of thermal processing and enzyme treatments of soybean meal on growth performance, ileal nutrient digestibility and chyme characteristics in broiler chicks. Poult. Sci., 76: 864-872.

Matoes, G. G. and J. L. Sell (1980). True and apparent metabolizable energy value of fat for laying hens. Influence of level of use. Poult. Sci., 59: 369-373.

Maurice, D. V. and L. S. Jensen (1978). Liver lipid deposition in caged layers as influenced by fermentation by-products and level of dietary fat. Poult. Sci., 57: 1690-1695.

Mckee, T. C. ; P. C. Harrison and G. L. Riskosski (1997). Effect of supplemental ascorbic acid on the energy concession of broiler chicks during heat stress and feed withdrawal. Poult. Sci., 76: 1278-1286.

Menge, H. ; E. C. Miller and C. A. Denton (1963). Effect of an essential fatty acid deficient diet on the reproductive performance of chickens. Poult. Sci., 42: 1291.

Mohamed, F. F. (1998). Nutrition and Immunity in Poultry. Egypt. J. Poult. Sci., 18: 443448.

Nagarajun, S. ; D. Narahari ; I. A. Japarasol and D. Thyagara (1991). Influence of stocking density and layer age on production traits and egg quality in Japanese quail. Br. Poult. Sci., 32(2): 243-248.

NRC (1994). Nutrient Requirements of Poultry. $9^{\text {th }}$ Ed. National Academy of Science Press, Washington, DC. USA.

Pardue, S. L. and J. P. Thaxton (1986). Ascorbic acid in poultry. A Review Worlds. Poult. Sci., 42: 107-123.

Pettersson, P. and P. Aman (1992). Production responses and serum lipid concentration of broiler chicken fed diets based on oat bran and extracted oat bran with and without enzyme supplementation. J. of the Sci. of Food and Agric. , 58: 569-576.

Ried, B. L. and C. W. Weber (1975). Supplemental dietary fat and laying hen performance. Poult. Sci., 54: 422-428.

Rowland, I. O. ; D. A. Roland and H. Harms (1973). Ascorbic acid as related to Tibia strength in spent eggs. Poult. Sci., 25: 347-350.

Sahata, A. W. and A. H. Gillani (1995). Effect of ascorbic acid supplementation on performance and cost of production in layer maintained under high ambient temperatures. Pakistan Veterinary Journa,l 15: 155-158.

SAS (1994). SPSS User's Guide Statistics. Ver. 10. Copyright SPSS Inc., USA.

Sell, J. L. ; L. G. Tenseuca and G. Bales (1979). Influence of dietary fat on energy utilization by laying hens. Poult. Sci., 58: 900-905.

Scragg, R. H. ; N. B. Logan and N. Geddes (1987). Response of egg weight to the inclusion of various fats in layers diets. Brt. Poult. Sci., 28: 15-21.

Shutzye, J. V. and L. S. Jensen (1962). Influence of linoleic acid on egg weight. Poult. Sci., 42: 921-924. 
Shutzye, J. V. ; L. S. Jensen and J. Meginnis (1959). Further studies on unidentified nutritional factor affecting egg size. Poult. Sci., 38: 1274.

Soliman, A. A. W. (1997). Evaluation of the productivity and performance of broiler breeder hens fed on particle or vegetable diets containing high levels of barley and sunflower meal with multi-enzymes supplement during the prelaying and laying period. Ph. D. Thesis, Fac. of Agric. Alex. Univ. Egypt.

Soliman, A. Z. M. (2003). Effect of ascorbic acid, enzymes mixture, form of feed and their interaction on layer hen performance during summer season. Egypt. Poult. Sci., 38: 1274.

Szczerbinska, D. (1998). Egg shell and hatachability and the relationship of these with age of hen. Animal Breeding Abstr., 66(8).

Takahashi, K. Y. and L. S. Jensen (1985). Reduction in hepatic lipid and plasma estradiol in ascorbic acid. Proceeding of the Society for Experimental Biology and Medicine.

Takahashi, K. Y. and M. Horignchi (1991). Effect of supplemental ascorbic acid on performance cholesterol concentration in broiler treated with propyl Thiouracil. Br. Poult. Sc.i. 32: 545-554.

Van der Klis, J. D. ; C. Kwakernauk and W. de Wit (1995). Effects of endoxylanase addition to wheat-based diets on physicochemical chyme condition and mineral absorption in broiler. Anim. Feed Sci., and Tech., 51: 15-25.

Vilchez, C. S. ; S. P. Touchburn ; E. R Chevez and C. W. Chan (1990). The influence of supplemental corn oil and free fatty acid on the reproductive performance of Japanese quail. Poult. Sci., 69: 1533-1538.

Weiss, J. F. ; E. C. Naber and R. M. Johanson (1964). Effect of some dietary factors and drugs and cholesterol concentration in the egg and plasma of the hen. J. Nutr., 91: 119-128.

Young, R. J. and R. I. Garrett (1963). Effect of oleic and linolic acid on the absorption of saturated fatty acids in the chick. J. Nutr., 81: 321-329.

Younis, T. M. (1981). Effect of source and level of fats on growth and fertility traits of some poultry breeds. Ph. D. Thesis Fac. of Agric., Azhar Univ.

Zakaria, A. H. and A. A. Al-Latif (1998). Effect of ascorbic acid treatment during egg incubation and after hatch on embryonic development hatch time and body weight changes of post hatch incubation time of broiler chickens. Arch. Geflugelk, 62(4): 176-182.

Zanella, I. ; N. K. Sakomura ; F. C. Silversids; A. Fiqueirdo and M. Pack (1999). Effect of enzyme supplementation of broiler diets based on corn and soybeans. Poult. Sci., 78: 561-568.

Zin-Ping Hung ; Lu Jin Jeen and J. C. Hsu (1998). Effects of dietary ascorbic acid supplementation on the laying performance, egg shell quality and immune response of laying hens under high ambient temperature. J. of Taiwan Livestock Res., 31: 101-114. 
تأثير بعض مصادر الزيوت والإضافات الغذائية للعليقة خلال الفترة المتأخرة لاورة إنتاج البيض

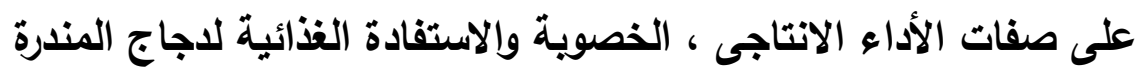

$$
\begin{aligned}
& \text { ممتاز محمد احمد شحاتة ـ السيد ايمن إبراهيم العبد } \\
& \text { محطة بحوث سخا- معهد بحوث الإنتاج الحيواني- مركز البحوث البرث الزئل الزر اعية- ج.م.ع. }
\end{aligned}
$$

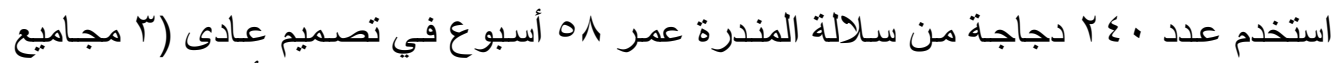

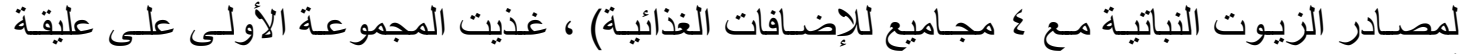

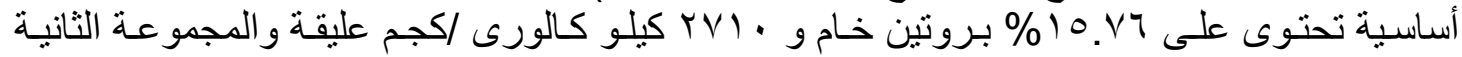

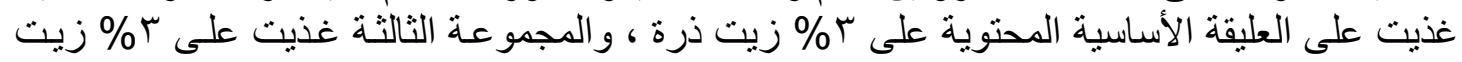

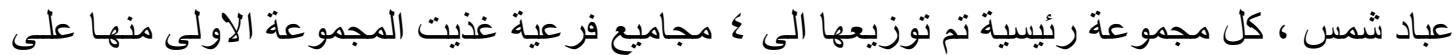

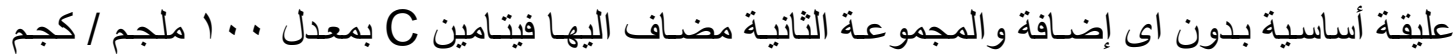

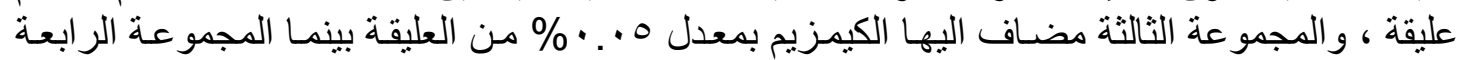
أضيف إلى عليقتها كلا من فيتامين C + الكيمزيم بنفس المعدلات السابقة معدل ه . . \% م من العليقة.

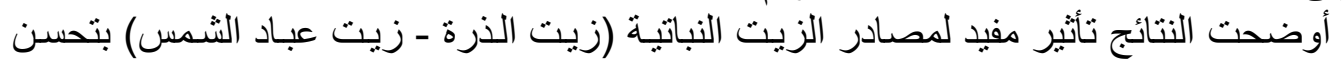

معاملات هضم CP, DM وكذلك EE بالإضـافة إلى كميـة الكالسيوم و الفوسفور المحتجزة بالمقارنة أشارت النتائج لتحسن قيم عدد البيض و إنتاج البيض وكتلة البيض والبض والكفاءة التحويلية وصفة بالعليقة القباسية

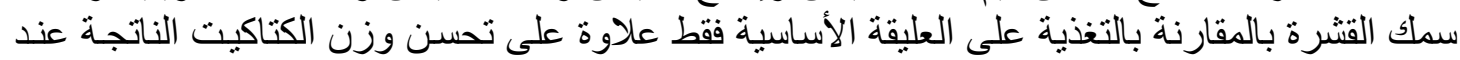

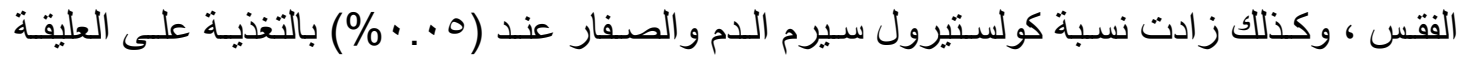
المحتوية س\% زيت ذرة وبالمقارنة بباقى المعاملات الأخرى.

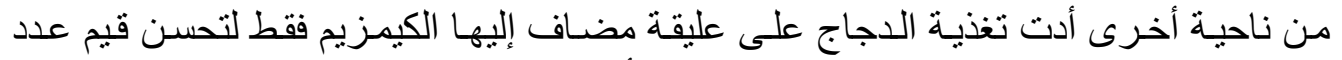
البيض و إنتاج البيض وكذلك الكفاعة التحويليـة ، في حين أدت تغذيـة الدجاج على عليقة مضـاف إليها فيتامين C لتحسن قيم وزن البيض وكتلة البيض بينما انخفض معدل الاستهلاك اليومي للعليقة بإضـافة

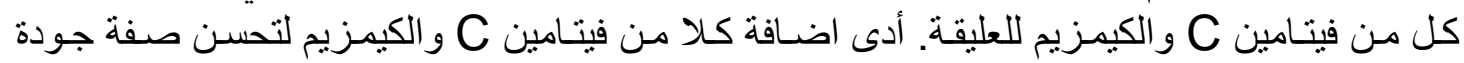

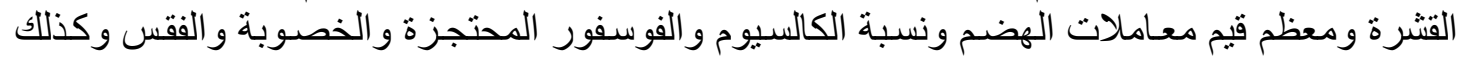
وزن الكتاكيت الفاقسة بينما انخفض كلا مـن كوليسترول سيرم الدم والصفار وز اد محتوى سيرم الدم

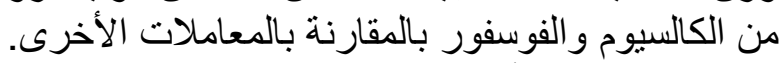

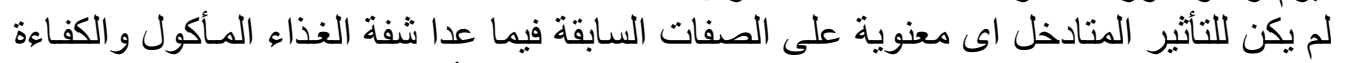
التحويلية وقيم كولستيرول سيرم الدم و الصفار و الليبيدات الكليـة التي أثرت عليها بشكل معندي معنوي عند

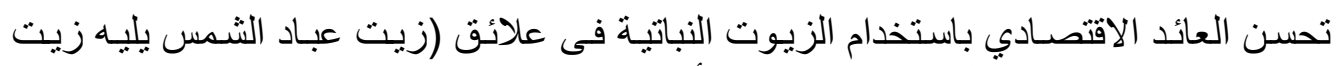

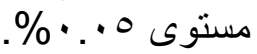

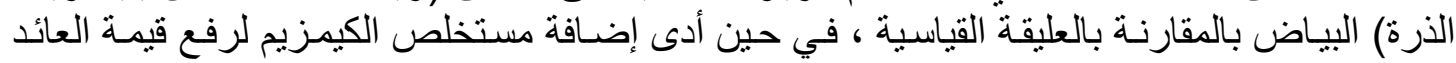
الاقتصـادى يليـة مخلوط فيتـامين C مـع الكيمـيم لعلائـق الـدجاج البيـاض مقارنـة بالمعـاملات الغذائيـة

توصى هذه الاراسة على إضـافة كلا من زيـت عبـاد الشـس أو زيت الذرة وكذلك مستخلص الاخرى.

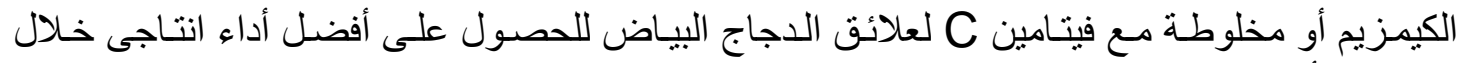
الفترة المتأخرة من دورة مأنتاج البيض. فين. 